\title{
Metoda zdalnego dopasowania implantu (telefitting) w Ogólnopolskiej Sieci Teleaudiologii
}

\section{The telefitting method used in the National Network of Teleaudiology}

\author{
Arkadiusz Wąsowski ${ }^{1,2}$, Henryk Skarżyński ${ }^{1,2}$, Łukasz Bruski ${ }^{3}$, Artur Lorens $^{1,2}$, \\ Anita Obrycka ${ }^{1,2}$, Adam Walkowiak ${ }^{1,2}$, Piotr H. Skarżyński ${ }^{1,3}$, Robert Lubański ${ }^{1,2}$ \\ ${ }^{1}$ Instytut Fizjologii i Patologii Słuchu, ul. Zgrupowania AK „Kampinos” 1, 01-943 Warszawa \\ ${ }^{2}$ Światowe Centrum Słuchu, ul. Mokra 17, Kajetany, 05-830 Nadarzyn \\ ${ }^{3}$ Instytut Narządów Zmysłów, ul. Mokra 1, Kajetany, 05-830 Nadarzyn
}

Adres autora: Arkadiusz Wąsowski, Światowe Centrum Słuchu, Zakład Implantów i Percepcji Słuchowej, ul. Mokra 17, Kajetany, 05-830 Nadarzyn

\section{Streszczenie}

Wprowadzenie: Dla uzyskania najlepszych wyników w zakresie poprawy słuchu, po założeniu implantu ślimakowego konieczne jest optymalne dopasowanie procesora mowy. Do niedawna większość pacjentów musiała odbyć długą podróż do ośrodka implantującego, co wiązało się z dużymi kosztami, stratą czasu i zmęczeniem spowodowanym podróżą. Problem ten może zostać rozwiązany poprzez zdalne dopasowanie implantu („telefitting”). Celem niniejszej pracy jest przedstawienie wyników wdrożenia klinicznego telefittingu na dużą skalę w ramach Ogólnopolskiej Sieci Teleaudiologii.

Materiał i metody: Materiał badawczy stanowiły 94 osoby korzystające z implantu ślimakowego, zakwalifikowane do telefittingu w okresie od marca do maja 2011 r. w jednym z 8 ośrodków wybranych do badania. Ocenę kosztów przeprowadzono na próbie 195 pacjentów.

Każdy pacjent odbył telekonsultacje, po której otrzymał do wypełnienia kwestionariusz, w którym pytano o jakość i czasochłonność telefittingu i przygotowań do zastosowania tej metody, ocenę łatwości kontaktu z audiologiem, poczucie bezpieczeństwa i spokoju podczas sesji oraz ogólną ocenę przydatności telefittingu jako alternatywy wobec typowych wizyt w ośrodku implantującym.

Wyniki i wnioski: Wykazano wysoką niezawodność Ogólnopolskiej Sieci Teleaudiologii jako platformy do metody telefittingu. Metoda oraz proponowany model opieki pooperacyjnej nad pacjentami z implantem z wykorzystaniem telemedycyny wydaje się stanowić dobrą alternatywę dla modelu tradycyjnego. Poprawia ona jakość usług świadczonych na rzecz pacjentów oraz pozwala na znaczne oszczędności czasu i pieniędzy.

Słowa kluczowe: telemedycyna • telefitting • implant ślimakowy

Abstract

Background: To obtain the best hearing benefits after cochlear implantation, the speech processor must be optimally fitted. The majority of patients have to undertake a long trip to the cochlear implant (CI) clinic, and this incurs high cost, time, and travel weariness. To overcome this problem, 'telefitting' has been proposed. The aim of this paper is to present the results of a large-scale introduction of telefitting into clinical practice.

Material and methods: Material of this study consisted of 94 cochlear implant users scheduled for telefitting between March and May 2011 in one of 8 centers selected for this study. For cost assessment a group of 195 patients was surveyed.

Each patient underwent a teleconsultation procedure. After telefitting the patient was presented with a questionnaire consisting of questions relating to the quality and time effectiveness of telefitting and the preparation process, assessment of the ease of contact with the audiologist, the sense of security and calm during the session, and an overall assessment of its usefulness as an alternative to different kinds of standard visits. 
Results and conclusions: The Nationwide Network of Teleaudiology proved to be a reliable platform for telefitting. The method and a proposed model of postoperative care for implanted patients using telemedicine seems to be a reliable alternative to standard model. It improves the quality of service provided to patients and saves substantial time and money.

Key words: telemedicine $\bullet$ telefitting $\bullet$ cochlear implant

\section{Wprowadzenie}

Dla uzyskania najlepszych wyników w zakresie poprawy słuchu po założeniu implantu ślimakowego konieczne jest zapewnienie pacjentowi dobrze zorganizowanej opieki pooperacyjnej. Jednym z najważniejszych zadań wchodzących w zakres tej opieki jest optymalne dopasowanie implantu ślimakowego. Zazwyczaj stosuje się tu specjalną procedurę, która wymaga odbycia przez pacjenta szeregu wizyt prowadzonych przez doświadczony, wielodyscyplinarny zespół w placówce zakładającej implanty ślimakowe (CI). Dla większości pacjentów wizyty te oznaczają konieczność odbywania długich podróży, co wiąże się często z wysokimi kosztami, pochłania dużo czasu oraz powoduje zmęczenie zmniejszające wiarygodność wyników testów i dopasowania. Ponadto gwałtowny wzrost liczby osób korzystających z implantu ślimakowego, jaki odnotowuje się w ostatnich latach, a także prognozowany dalszy rozwój sytuacji w tym zakresie, stawiają dodatkowe wyzwania logistyczne dla standardowych, klasycznych wizyt pacjentów w ośrodku implantującym.

Jednym z proponowanych rozwiązań powyższych problemów jest powierzenie realizacji pewnych elementów procedury mniejszym ośrodkom współpracującym położonym na terenie kraju. Ośrodki takie posiadają na ogół niezbędne wyposażenie, a także zespół mogący świadczyć usługi medyczne i rehabilitacyjne na zadowalającym poziomie. Zespoły takie nie mogą jednakże zrealizować pewnych elementów procedury, jak pomiary psychofizyczne lub programowanie implantu ślimakowego, $\mathrm{z}$ uwagi na brak wystarczającego doświadczenia w tym zakresie. Problem ten proponuje się rozwiązać poprzez wykorzystanie telemedycyny. Pozwala to na realizację przez współpracujące przychodnie części procedury obejmującej badanie laryngologiczne, testy audiologiczne oraz ocenę rehabilitacji. Na tym etapie doświadczeni specjaliści z placówki CI wspierani przez personel lokalny realizują końcową, najważniejszą część procedury: pomiary psychofizyczne i obiektywne oraz programowanie procesora mowy.

Podstawy tego podejścia były opisane w ostatnich latach [1-3]. Internet pozwala specjalistom z placówki CI na zorganizowanie telekonferencji umożliwiającej kontakt słuchowy i wzrokowy z pacjentem oraz personelem pomocniczym, a oprogramowanie zdalnego pulpitu pozwala na przejęcie kontroli nad odległym komputerem umożliwiając przeprowadzenie pomiarów i dopasowania. Metodę tę poddano ocenie w warunkach kontrolowanych, w których pacjenci poddawani są procedurze dopasowania implantu dwukrotnie: w ramach osobistego kontaktu oraz w trybie symulowanego dopasowania zdalnego, przeprowadzanego zazwyczaj w tym samym budynku, lecz z zastosowaniem technologii z zakresu telemedycyny. Badania te dowiodły, że telefitting jest bezpieczny, niezawodny i dobrze przyjmowany zarówno przez pacjentów, jak i przez specjalistów. Parametry stymulacji elektrycznej uzyskiwane podczas telefittingu nie różnią się znacznie od wartości, jakie uzyskuje się podczas tradycyjnego dopasowania w osobistym kontakcie z pacjentem.

Trudno jest jednakże znaleźć opis wyników wprowadzenia proponowanej metody do praktyki klinicznej, a zwłaszcza informacje o tym, jak pacjenci oceniają rzeczywistą jakość usługi pozbawionej wsparcia w postaci drugiego, tradycyjnego dopasowania. Brak jest także oszacowania możliwych do osiągnięcia rzeczywistych oszczędności finansowych i czasowych.

\section{Cel}

Celem pracy jest przedstawienie wyników wprowadzenia telefittingu na dużą skalę do praktyki klinicznej w oparciu o doświadczenia zgromadzone podczas codziennego korzystania z Ogólnopolskiej Sieci Teleaudiologii.

\section{Material}

Materiał badawczy stanowiły 94 osoby korzystające z implantu ślimakowego, zakwalifikowane do telefittingu w okresie od marca do maja 2011 r. w jednym z 8 ośrodków w Polsce. Cała sieć obejmuje 20 ośrodków; na potrzeby badania wybrano 8 spośród nich. Kryteria zakwalifikowania do badania obejmowały także zdolność pacjenta do dokonania wiarygodnej oceny przebiegu i wyniku telefittingu oraz do wypełnienia kwestionariusza, w grupie badanej znalazły się zatem jedynie osoby dorosłe oraz starsze dzieci spełniające te wymagania. Średnia wieku pacjentów wyniosła 34,5 lat, mediana - 30,5 lat, odchylenie standardowe - 16,9, przy czym najmłodszy pacjent miał 12 lat, a najstarszy - 86 lat. Średni czas użytkowania implantu ślimakowego (od pierwszego dopasowania) wynosił 57 miesięcy, mediana - 48 miesięcy, odchylenie standardowe -42 miesiące, przy czym najkrótszy okres korzystania $\mathrm{z}$ implantu wynosił 6 miesięcy, a najdłuższy - 17 lat. Pacjenci korzystali z różnych implantów ślimakowych: $73,4 \%$ z urządzeń MED-EL, 23,4\% z urządzeń Cochlear, a 3,2\% $\mathrm{z}$ urządzeń Advanced Bionics.

Na potrzeby oceny kosztów wybrano grupę 195 pacjentów leczonych w jednej z 5 reprezentatywnych przychodni z całej Polski. W grupie wybranej do objęcia badaniem 41 osób podchodziło $\mathrm{z}$ województwa podkarpackiego, 38 osób z pomorskiego, 46 osób z warmińsko-mazurskiego, 29 osób z województwa śląskiego, a 41 z zachodniopomorskiego.

\section{Metoda}

Ogólnopolską Sieć Teleaudiologii wprowadzono w roku 2009 w celu zapewnienia szerokiego wachlarza zastosowań tele-zdrowotnych, takich jak telefitting, telediagnostyka, telerehabilitacja lub teleedukacja. Obejmuje ona 20 ośrodków współpracujących w Polsce oraz 1 na Ukrainie (Rycina 1). Ośrodkiem centralnym sieci jest Światowe 


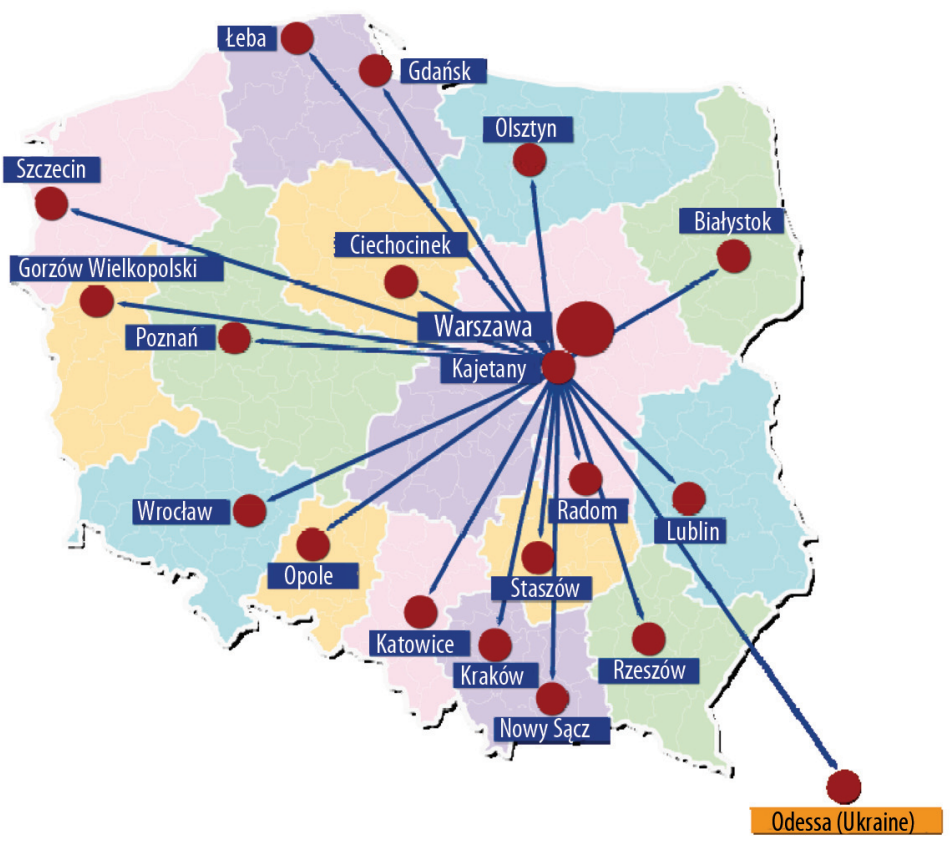

Rycina 1. Ogólnopolska Sieć Teleaudiologii

Centrum Słuchu w Kajetanach, skąd doświadczeni specjaliści zapewniają opiekę telemedyczną pacjentom przychodni współpracujących. Każdy węzeł wyposażony jest w terminale telekonferencyjne HDX8006 produkcji Polycom Inc. z ekranami LCD 32", ruchomymi kamerami Polycom z funkcją zoom, oraz podłączeniem do systemu z symetrycznymi łączami internetowymi o przepustowości 2 Mbit/s. W każdym węźle znajduje się komputer klasy PC z odpowiednimi interfejsami klinicznymi oraz oprogramowaniem do dopasowywania implantów. Funkcjonalność pulpitu zdalnego zapewnia aplikacja Longmein.com. W ośrodkach współpracujących przeszkolonych zostało ponad 40 specjalistów wspomagających. Podczas telefittingu wspierają oni proces komunikacji z pacjentem oraz są odpowiedzialni za podstawowe czynności techniczne, jak podłączenie procesora mowy do interfejsu.

Każdy pacjent odbył telekonsultacje zgodnie z procedurą stworzoną dla użytkowników implantów ślimakowych i wprowadzoną do praktyki klinicznej w Ogólnopolskiej Sieci Teleaudiologii. Celem tej procedury była wierna emulacja procedury tradycyjnej stosowanej podczas osobistych wizyt pacjenta w placówce CI. Procedura telekonsultacji obejmuje badanie laryngologiczne, etap przygotowawczy oraz sam telefitting. Na etapie przygotowawczym specjalista wspomagający przeprowadza z pacjentem zorganizowany wywiad dotyczący poprawy słuchu, umiejętności komunikacyjnych oraz typowego korzystania $z$ implantu w życiu codziennym. Kolejny etap obejmuje pomiary psychoakustyczne - audiometrię pola swobodnego oraz audiometrię mowy $\mathrm{z}$ wykorzystaniem słów jednosylabowych w ciszy oraz z zastosowaniem szumu (SNR 10dB), odpowiednio do umiejętności pacjenta. Ostatnia część przygotowań obejmuje konsultacje z miejscowym logopedą, z możliwością omówienia problemów słuchowych i komunikacyjnych.

Podczas drugiej części - telefittingu - specjalista ze Światowego Centrum Słuchu omawia z pacjentem i logopedą z personelu pomocniczego odpowiedzi udzielone $\mathrm{w}$ kwestionariuszu. Następnie specjalista wspomagający podłącza do interfejsu procesor mowy, a audiolog przejmuje kontrolę nad komputerem zdalnym. Wykonuje się wówczas pomiary obiektywne: pomiary impedancji, ECAP i/lub ESR zależnie od potrzeb danego pacjenta. Na kolejny etap składają się pomiary psychofizyczne, takie jak elektrycznie wywołana funkcja narastania głośności, detekcja progowa lub ewaluacja MCL, przy czym stopień trudności zadań dostosowuje się do możliwości pacjenta. Końcowy etap to stworzenie nowego programu oraz uzyskanie pierwszych informacji zwrotnych od pacjenta w trybie „na żywo”. We wszystkich etapach aktywny udział bierze specjalista wsopmagający. Badanie laryngologiczne oraz etap przygotowawczy trwają na ogół 1 godzinę, a telefitting - od 45 minut do 1 godziny.

Po telefittingu pacjent otrzymał do wypełnienia kwestionariusz, w którym pytany był o jakość i czasochłonność telefittingu i przygotowań do zastosowania tej metody, ocenę łatwości kontaktu z audiologiem, poczucie bezpieczeństwa i spokoju podczas sesji oraz ogólną ocenę przydatności telefittingu jako alternatywy wobec typowych wizyt w ośrodku implantującym.

Czas dojazdu oraz odległość, jaką pacjent musiałby przebyć korzystając z własnego samochodu, by dotrzeć do Międzynarodowego Centrum Słuchu i Mowy lub do jednej z przychodni satelitarnych obliczono na podstawie adresu zamieszkania pacjenta oraz adresu placówki. W badaniu posłużono się portalem Google Maps. Następnie obliczoną odległość pomnożono przez średnią stawkę za kilometr w przypadku korzystania z samochodu prywatnego (o pojemności skokowej silnika $900 \mathrm{~cm}^{3}$ ) do celów służbowych (podaną w rozporządzeniu Ministra Infrastruktury z 2007 r.). Wynik stanowił podstawę do obliczenia oszczędności czasowych i finansowych związanych z korzystaniem przez pacjenta z możliwości zdalnego dopasowania procesora mowy. 
Tabela 1. Wyniki badania kwestionariuszowego

\begin{tabular}{|c|c|c|c|c|c|}
\hline & $\begin{array}{l}\text { Zdecydowanie } \\
\text { się nie } \\
\text { zgadzam }\end{array}$ & $\begin{array}{c}\text { Nie } \\
\text { zgadzam się }\end{array}$ & $\begin{array}{l}\text { Trudno } \\
\text { powiedzieć }\end{array}$ & $\begin{array}{c}\text { Zgadzam } \\
\text { się }\end{array}$ & $\begin{array}{l}\text { Zdecydowanie } \\
\text { się zgadzam }\end{array}$ \\
\hline Jakość połączenia audio-wideo jest dobra & 0 & 4 & 1 & 33 & 56 \\
\hline Miałem dobry kontakt z audiologiem & 0 & 2 & 5 & 35 & 52 \\
\hline $\begin{array}{c}\text { Czułem się bezpiecznie i pewnie podczas } \\
\text { telefittingu }\end{array}$ & 0 & 1 & 3 & 33 & 57 \\
\hline $\begin{array}{c}\text { Jestem zadowolony z przebiegu i efektów } \\
\text { telefittingu }\end{array}$ & 0 & 0 & 5 & 38 & 51 \\
\hline $\begin{array}{l}\text { Telefitting to dobra alternatywa wobec } \\
\text { tradycyjnego dopasowania }\end{array}$ & 0 & 0 & 4 & 32 & 58 \\
\hline $\begin{array}{l}\text { Telefitting pozwolił mi zaoszczędzić czas } \\
\text { i pieniądze }\end{array}$ & 0 & 0 & 3 & 22 & 69 \\
\hline
\end{tabular}

Tabela 2. Ocena ogólna

\begin{tabular}{cccc}
\hline & Nie & Nie mam zdania & Tak \\
\hline $\begin{array}{c}\text { Telefitting jest dobrą alternatywą dla wizyt pierwszego } \\
\text { dopasowania }\end{array}$ & 21 & 42 & 31 \\
\hline $\begin{array}{c}\text { Telefitting jest dobrą alternatywą wobec tradycyjnych } \\
\text { wizyt kontrolnych }\end{array}$ & 3 & 5 & 86 \\
\hline \begin{tabular}{c} 
Będę korzystać z telefittingu w przyszłości \\
\hline
\end{tabular} & 0 & 6 & 88 \\
\hline
\end{tabular}

\section{Wyniki}

Wyniki ocen dokonywanych przez pacjentów przedstawia Tabela 1. W większości przypadków pacjenci zgodzili się lub zdecydowanie się zgodzili z twierdzeniami dotyczącymi dobrej jakości połączenia audio-wideo i kontaktu $\mathrm{z}$ audiologiem. W czterech z pięciu przypadków, gdzie jakość połączenia audio wideo nie została oceniona jako dobra, także kontakt $\mathrm{z}$ audiologiem uzyskał gorszą ocenę, a poczucie bezpieczeństwa pacjenta okazało się niezadowalające. Można założyć, że ogólna zdolność komunikacji tych pacjentów była ograniczona. Ogólnie pacjenci byli bardzo zadowoleni z przebiegu i wyniku telefittingu, choć pięciu pacjentów udzieliło odpowiedzi „trudno powiedzieć”. Jednakże tylko dwie osoby spośród tych pięciu pacjentów nie zgodziły się z twierdzeniem, że telefitting jest dobrą alternatywą wobec tradycyjnych wizyt w przychodni. Kolejne 2 osoby, które nie zgodziły się $\mathrm{z}$ tym twierdzeniem, odpowiedziały „zgadzam się” lub „zdecydowanie się zgadzam" na pozostałe pytania. W 3 przypadkach nie wystąpiły oszczędności czasowe lub finansowe $z$ uwagi na nieprzewidziane komplikacje w drodze do ośrodka satelitarnego.

Tabela 2 przedstawia ogólną ocenę nowej procedury dokonaną przez pacjentów. Większość pacjentów zgodziła się z twierdzeniem, że telefitting jest dobrą alternatywą wobec tradycyjnych wizyt kontrolnych, lecz tylko 31 osób uznało, że metodę tę należy stosować także przy pierwszym dopasowaniu, co potwierdza opinię autorów, iż pierwsze dopasowanie powinno się wykonywać w sposób tradycyjny. Przeważająca większość (93\%) pacjentów korzystałaby z telefittingu w przyszłości; tylko 6 spośród 94 osób nie miało co do tego pewności, a żaden $\mathrm{z}$ respondentów nie udzielił odpowiedzi przeczącej.

Pacjentów proszono też o ocenę czasu, jaki zaoszczędziliby odwiedzając położoną bliżej ich domu przychodnię satelicką. Średnie oszczędności czasowe pacjentów wyniosłyby 10,5 godziny, odchylenie standardowe $-8,85$ godziny. Najmniejsze wspomniane oszczędności czasowe to $40 \mathrm{mi}$ nut, największe - 48 godzin.

Jak wynika z oceny obniżki kosztów, przeprowadzonej na większej grupie 195 pacjentów, średnie oszczędności wynoszą aż 12,5\% średniej wynagrodzenia krajowego. Z tej samej analizy wynika, że czas podróży skrócił się średnio o 8 godzin i 19 minut, co z niewyjaśnionych powodów różni się od wyników uzyskanych $\mathrm{z}$ wywiadu kwestionariuszowego $\mathrm{z}$ pacjentami. Zdaniem autorów różnica ta mogła wynikać z zaokrągleń dokonanych przez pacjentów przy wypełnianiu kwestionariuszy, a także z doliczenia czasu odpoczynku, w tym niekiedy noclegu na miejscu po wizycie $\mathrm{w}$ placówce, oraz $\mathrm{z}$ wydłużenia czasu podróży w związku z trudnościami w ruchu drogowym.

\section{Omówienie}

Ogólnopolska Sieć Teleuadiologii, wprowadzona do praktyki klinicznej w Instytucie Fizjologii i Patologii Słuchu, okazała się niezawodną platformą telefittingu. Metoda i proponowany model pooperacyjnej opieki nad pacjentami $\mathrm{z}$ implantem wydają się stanowić dobrą alternatywę wobec modelu tradycyjnego, podnosząc jakość usług dla pacjentów oraz zapewniając znaczne oszczędności czasowe 
i finansowe. Jednocześnie niektórzy pacjenci mogą czuć się niezręcznie w środowisku telemedycznym - w przypadku takich osób należy stosować tradycyjną opiekę pooperacyjną.

Ogólnopolska Sieć Teleaudiologii może wywierać bardzo duży wpływ na opiekę zdrowotną, umożliwiając świadczenie usług wysokiej jakości za pośrednictwem technologii teleinformatycznych na rzecz grup objętych niedostateczną opieką w Polsce i zagranicą [4].

Obecnie istnieje duża grupa pacjentów z występującym $\mathrm{w}$ różnym nasileniu niedosłuchem $\mathrm{w}$ obrębie niskich częstotliwości i towarzyszącym całkowitym niedosłuchem dla częstotliwości wysokich; osoby te pozostają zasadniczo poza zasięgiem skutecznego leczenia $\mathrm{z}$ użyciem aktualnie dostępnych protez słuchowych, w tym aparatów słuchowych i implantów ślimakowych w ich tradycyjnym ujęciu.
Ten rodzaj ubytku słuchu nazwano "częściową głuchotą" (PD) [5-7]. Pacjentów takich nie kwalifikuje się jeszcze na szeroką skalę do założenia implantu ślimakowego z uwagi na obawę, że interwencja chirurgiczna może uszkodzić ich szczątkowy słuch w obrębie niskich częstotliwości; wymagają oni ponadto bardziej złożonego dopasowania po zabiegu. W tej sytuacji Ogólnopolska Sieć Teleaudiologii, która usuwa barierę odległości pomiędzy pacjentami a specjalistami w zakresie leczenia także częściowej głuchoty oraz pozwala na zdalne dopasowanie, może przyczynić się do gwałtownego wzrostu liczby kandydatów z PD. Specjaliści praktykujący telemedycynę mogą teraz wywrzeć globalny wpływ na stosowanie CI.

Autorzy żywią przekonanie, iż proponowana metoda podniesie jakość opieki pooperacyjnej po założeniu implantu ślimakowego; metoda telefittingu może i powinna stanowić część normalnej praktyki klinicznej.

\section{Piśmiennictwo:}

1. Wesarg T., Wasowski A., Skarzynski H. i wsp.: Remote fitting in Nucleus cochlear implant recipients [Zdalne dopasowywanie u pacjentów z implantem ślimakowym Nucleus]. Acta Otolaryngol, 2010; 130(12): 1379-88

2. Wasowski A., Skarzynski P.H., Lorens A. i wsp.: Remote fitting of cochlear implant system [Zdalne dopasowywanie implantu ślimakowego]. Cochlear Implants Int, 2010; 11(1): 489-92

3. Rodriguez C., Ramos A., Falcon J.C. i wsp.: Use of telemedicine in the remote programming of cochlear implants [Zastosowanie telemedycyny w zdalnym programowaniu implantów ślimakowych]. Cochlear Implants Int, 2010; 11(1): 461-64

4. Polovoy C.: Audiology telepractice overcomes inaccessibility [Telepraktyki audiologiczne rozwiązują problem braku dostępności]. The ASHA Leader, 2008; 13(8): 20-22

5. Skarzynski H., Lorens A., Piotrowska A.: A new method of partial deafness treatment [Nowa metoda leczenia głuchoty częściowej]. Med Sci Monit, 2003; 9(4): CS20-24
6. Skarzynski H., Lorens A., Piotrowska A., Anderson I.: Preservation of low frequency hearing in partial deafness cochlear implantation (PDCI) using the round window surgical approach [Zachowanie słyszenia niskich częstotliwości w przypadku implantów ślimakowych głuchoty częściowej (PDCI) z wykorzystaniem panoramicznego podejścia chirurgicznego]. Acta Otolaryngol, 2007; 127: 41-48

7. Skarzynski H., Lorens A.: Partial deafness treatment [Leczenie głuchoty częściowej]. Cochlear Implant Int, 2010; 11(Suppl.1): 29-41

8. Skarzynski H., Lorens A., Piotrowska A., Skarzynski P.: Hearing Preservation In partial deafness treatment [Zachowanie słyszenia w leczeniu głuchoty częściowej]. Med Sci Monit, 2010; 16(11): CR555-62 